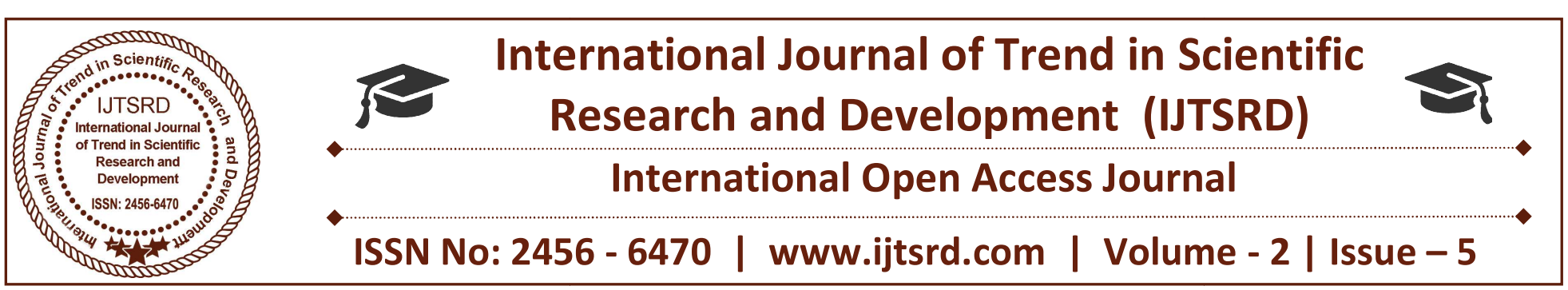

\title{
Assessment of Permeability Characteristics of Ado-Ekiti to Ikere- Ekiti Road Soil, Southwestern Nigeria
}

\author{
Adeyemi E. Adetoro, Samuel O. Akinlolu \\ Lecturer, Department of Civil Engineering, The Federal Polytechnic, P.M.B. \\ Ado - Ekiti, Nigeria, West Africa
}

\begin{abstract}
There is need for good knowledge of soil permeability in order to estimate the quantity of fluid or water flow in soil, which will help in building and maintaining good road. The study sought to assess the permeability characteristics of Ado-Ekiti to IkereEkiti road soil. Soil samples were taken from ten locations, subjected to permeability tests in Laboratory and the results analysed. Results showed that that the permeability values obtained from grain size and falling head methods varied from $1.73 \times 10-6$ $\neg$ to $2.15 \times 10-3 \mathrm{~mm} / \mathrm{s}$ and $8.46 \times 10-2 \neg$ to $1.23 \times 10-1$ $\mathrm{cm} / \mathrm{s}$ respectively for all the soil samples. These showed that some soil samples have high permeability, while others have low permeability. Though all the soil samples were well-graded. Thus, soil with high permeability portrayed high contents of granular materials (sand), while that of low permeability portrayed high contents of clay and its minerals. There is need for further study.
\end{abstract}

Keywords: Falling Head; Grain Size; Permeability; Road, Soil; Well-graded

\section{INTRODUCTION}

One of the most natural resources important to the existence of any facet of human life is water. However, throughout the world today, water is the main enemy of every road irrespective of the climate. This usually occurs when water rises through the capillaries into the road, consequentially, the road fails. When there are pressure and vibration of vehicles on this affected part of road, the soil becomes plastic [3]. The existence of linked voids that allow the flow of fluids when change in energy head occurs showed that soils are permeable materials. There is need for good knowledge of soil permeability in order to estimate the quantity of water or fluid flow in soil [8].
[5] Expressed that the effect of water on the structural support of the pavement system depends upon saturated fine-grain roadbed soil, which could experience modulus reduction of more than $50 \%$. Moreover, it portrayed that if the subgrade permeability is less than $3 \mathrm{~m} /$ day (in wet climate), some form of subsurface drainage or other design characteristics should be considered in order to combat potential moisture banes.

Permeability is the property of a porous material, which allows the passage or seepage of water through its interconnecting void. The coefficient of permeability is defined as "the rate of discharge of water at $20^{\circ} \mathrm{C}$ under conditions of laminar flow through a unit cross-sectional area of a soil medium under a unit hydraulic gradient". It is used to assess drainage characteristics of soil and predict rate of settlement founded on soil bed.The performance of a pavement depends on the quality of its sub-grade and sub-base layers. As the foundation for the pavement's upper layers, the sub-grade and sub-base layers play a key role in mitigating the detrimental effects of climate and the static and dynamic stresses generated by traffic. Therefore, building a stable sub-grade and a properly drained sub-base is vital for constructing an effective and long lasting pavement system. The permeability of pavement layers in a typical road must be in descending order of subgrade $>$ subbase $>$ base $([4],[8])$.

In addition to stability and drainage requirements, the sub-grade and sub-base must be designed and constructed to exhibit a high level of spatial uniformity measured using engineering parameters. Several environmental variables (e.g. temperature, moisture etc.) must also be taken into account, since 
these variables have both short and long term effects on the geotechnical characteristics of the soil ([4], $[8])$.

The effect of permeability on groundwater flow occurs when a rock that has high porosity is not permeable, if the pores or fractions are not connected. The larger and better shorted the particles, the more permeable rock or sediment tends to be. Effects of permeability characteristics on pavement layers performances generally depend on two interrelated characteristics namely load bearing capacity and volume changes. Load bearing capacity is often affected by degree of compaction, moisture content and soil type. While volume changes occur when pavement layers (i.e. base, sub base and sub grade) are exposed to excessive moisture or freezing conditions ([4], [8]).

Permeability Tests are frequently used in the assessment of permeability in compacted soils in landfill and road construction. Soil permeability also known as "Hydraulic conductivity" is measured using many methods inclusive of Constant and Falling Heads laboratory tests on disturbed or undisturbed samples. During the test (s), there should be no volume change in the soil, there should be no compressible air present in the voids of soil i.e. soil should be completely saturated. The flow should be laminar and in a steady state condition. Permeability can be measured in the field using in-situ borehole permeability and field pumping tests. Another means is to experimentally derive coefficients of permeability from the results of simple laboratory tests such as the Grain size distribution. Anyway, soil permeability had also been estimated using Cone penetration tests [8].

Many investigations carried out over the years for assessment of permeability characteristics of sub grade soil (which has been one of the criteria for road stability) indicated that there have been no accepted standard with reference to its characteristics performance thus bring about questions on its acceptability for highway construction [3].
The aim of this research work is to assess the permeability characteristics of Ado-ekiti to Ikere-ekiti road soil, South-western Nigeria. The test to be carried out is permeability test, which will help in determining the rate of flow of water/fluid in the road's soil. These data would be useful to Engineers and other professionals. The coefficient of permeability was measured using laboratory falling head method. The measured permeability values were compared to the values experimentally derived from grain size distribution. Moreover, the coefficients of permeability were obtained using correlation based on the index soil properties of the tested soil for comparison with the measured values.

\section{A. Study Area}

The study area is along Ado Ekiti - Ikere Ekiti road connecting Ado - Ekiti and Ikere - Ekiti Local Government Areas (LGAs) together. It is about 14.4 $\mathrm{km}$ and lies within Latitude $7^{0} 30^{1} 7.500^{\circ} \mathrm{N}$ and Longitude $5^{0} 14^{1} 5.233^{\circ} \mathrm{E}$ as shown in fig. 1. Geologically, its landscape consists of ancient plains broken by steep sided outcropping dome rocks situated within tropical climate of Nigeria and underlain by metamorphic rocks of the Precambrian basement complex of Southwestern Nigeria, which are very ancient in age as shown in fig. 2. These basement complex rocks showed great variations in grain size and in mineral composition. The rocks are quartz gneisses and schists consisting essentially of quartz with small amounts of white mizageous minerals. In grain size and structure, the rocks vary from very coarse-grained pegmatite to mediumgrained gneisses ([1], [2], [7]).

The rocks are strongly foliated and occur as outcrops. The soils derived from the basement complex rock are mostly well drained, having medium to coarse in texture. The geological nature of the study area and its increased urbanisation make it more vulnerable and of public health concern when it comes to water quality ([1], [2], [7]). 


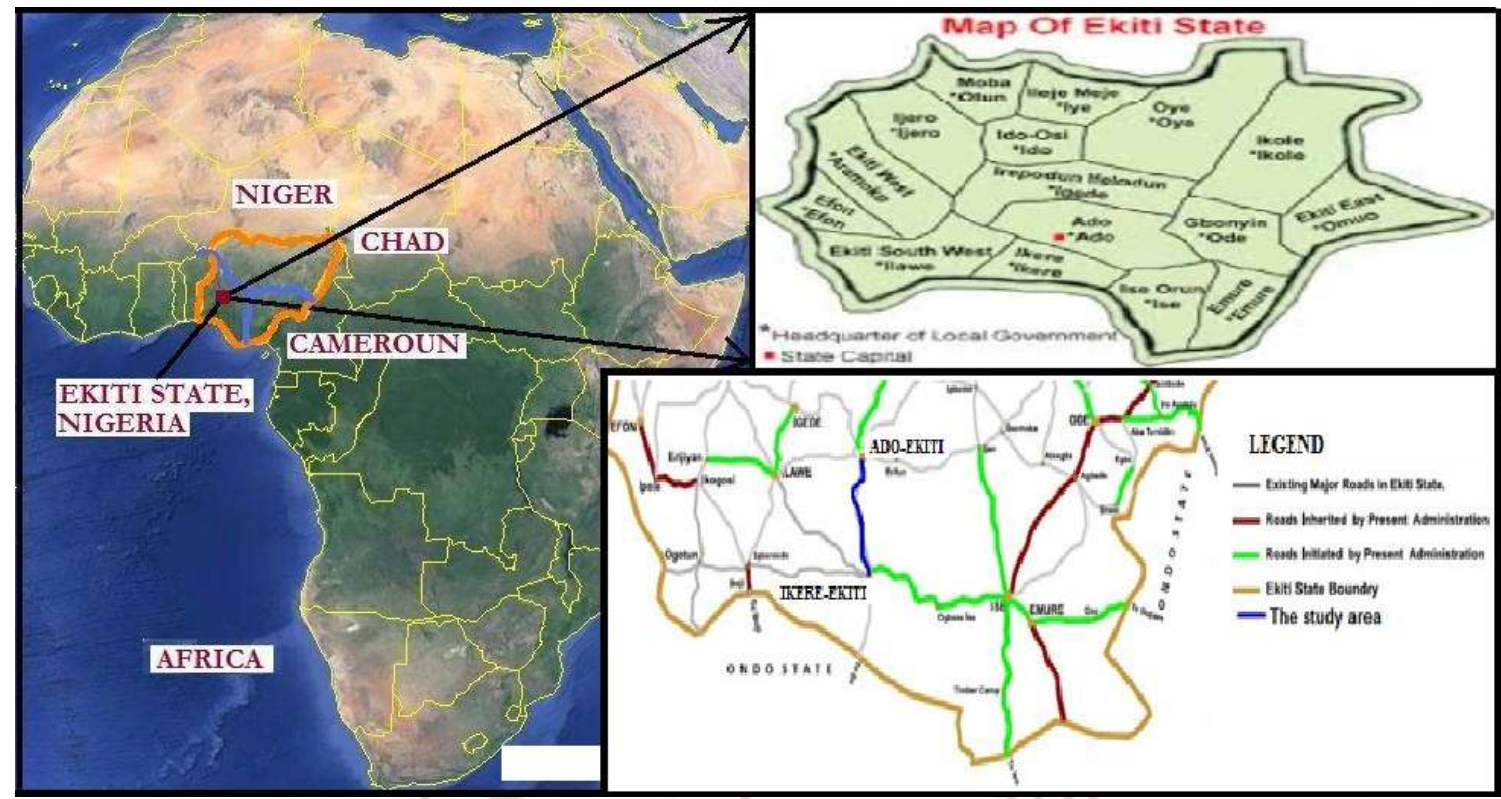

Figure 1: Location of the Study Area- Ado-Ekiti to Ikere-Ekiti Road, Ekiti State, Nigeria
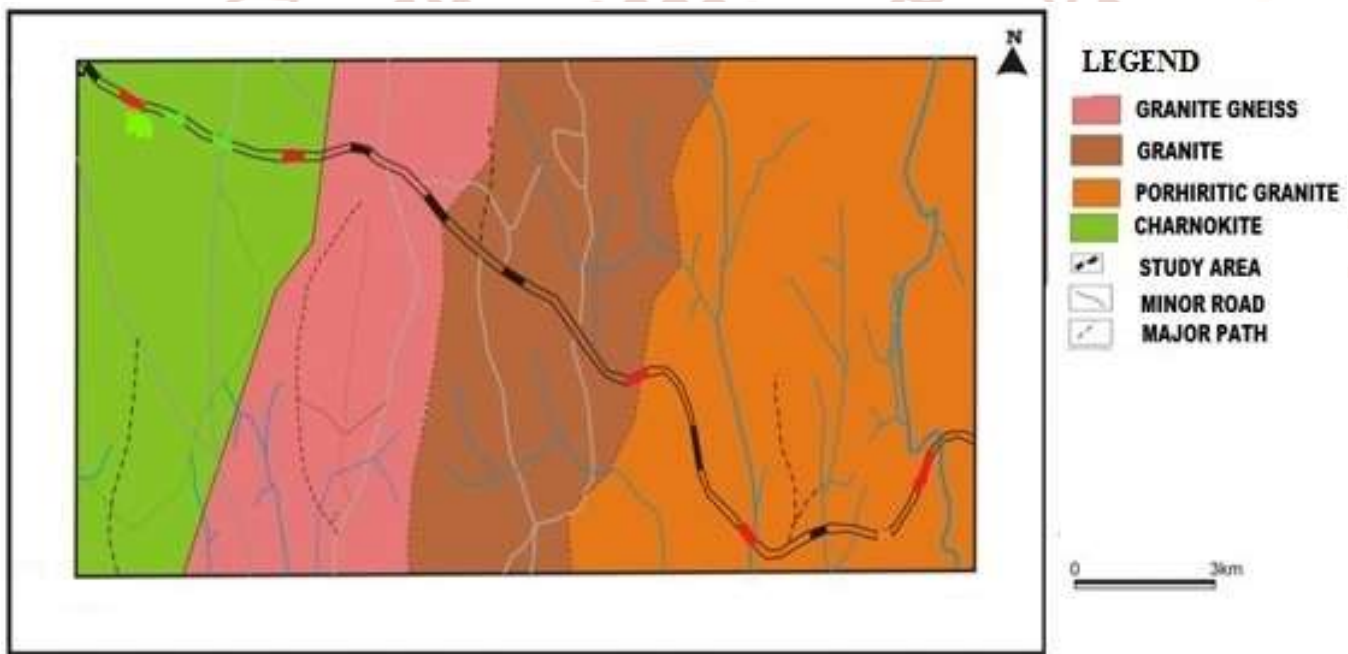

Figure 2: Geology of the Study Area - Ado-Ekiti to Ikere-Ekiti Road, Ekiti State, Nigeria

\section{MATERIALS AND METHODS \\ A. Sample Collection and Analysis}

The whole stretch of the road was visually inspected and soil samples were taken from ten pits (i.e. locations) dug within the study area at interval of $500 \mathrm{~m}$ and depth between $0.50 \mathrm{~m}$ and $1.5 \mathrm{~m}$ after topsoil removal using method of disturbed sampling. The soil samples collected were stored in polythene bag to maintain its natural moisture contents. The samples were then taken to the laboratory where the deleterious materials such as roots were removed. The samples were air dried, pulverized and large particles were removed. The coordinates of collected soil samples locations were taken using GPS. The details of the soil samples were as shown in Fig. 3 and Table 1. Moulding of test specimens was started as soon as possible after completion of identification. The tests carried out on the samples were Grain Size
Distribution and Falling Head Permeability. All tests were performed in accordance with [6] standards and [5] specifications.
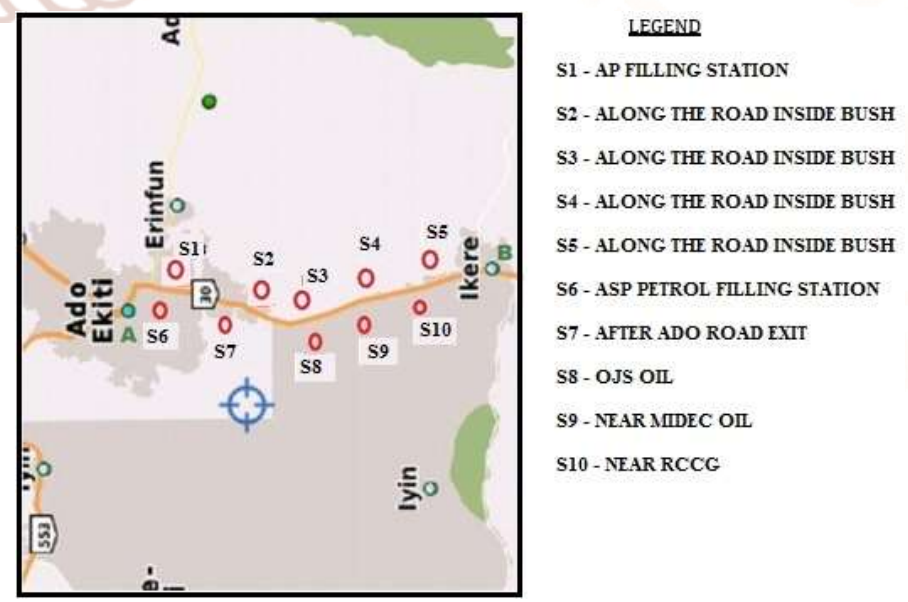

Figure 3: Topographical Map of the Sampling locations 
Coefficient of Uniformity $\left(\mathrm{C}_{\mathrm{u}}\right)$ was calculated from Grain size grading curve using Hazen formula as shown in equation (1).

$$
\mathrm{C}_{\mathrm{u}}=\mathrm{D}_{60} / \mathrm{D}_{10}
$$

Where $\mathrm{D}_{60}$ and $\mathrm{D}_{10}$ were obtained from the grading curve and it corresponds to the percentage passing at 60 percent and 10 percent respectively.in $\mathrm{mm}$. When $\mathrm{C}_{\mathrm{u}}>5$, it indicates a well graded soil, while $\mathrm{C}_{\mathrm{u}}<3$ indicates a uniform soil. Permeability was calculated using McKinley formula as shown in equation (2).

$$
\mathrm{K}=\mathrm{CD}^{2}{ }_{50}
$$

Where $\mathrm{K}$ is permeability $(\mathrm{mm} / \mathrm{sec}), \mathrm{C}$ is McKinley's constant which is approximately 0.00357 and $\mathrm{D}_{50}$ is maximum diameter of the smallest 50 percent of the sample.
For the Falling (Variable) Head permeability test, permeability is expressed as:

$$
\mathrm{K}=(2.303 \mathrm{aL} / \mathrm{A} . \mathrm{T}) \log _{10}\left(\mathrm{~h}_{1} / \mathrm{h}_{2}\right)
$$

Where $\mathrm{K}$ is the coefficient of permeability at $\mathrm{T}^{0} \mathrm{C}$ $(\mathrm{cm} / \mathrm{sec}$.). a is the cross-sectional area of stand pipe $\left(\mathrm{cm}^{2}\right)$. L is the length of soil specimen (cm). A is the cross-sectional area of the soil specimen $\left(\mathrm{cm}^{2}\right)$. $\mathrm{T}$ is the average value of $t_{1}$ and $t_{2}$, where $t_{1}$ and $t_{2}$ are the time interval for the head to fall from $h_{1}$ to $h_{2}$ (secs.). While $h_{1}$ and $h_{2}$ are the initial heads of water at times $t_{1}$ and $t_{2}$ in the pipe above the outlet $(\mathrm{cm})$ respectively (cm). When $\mathrm{K}>10^{-1} \mathrm{~cm} / \mathrm{sec}$., permeability is high, $\mathrm{K}$

\begin{tabular}{|c|c|c|c|}
\hline $\begin{array}{l}\text { SAMPLE } \\
\text { CODE }\end{array}$ & LOCATION & DESCRIPTION & COORDINATES \\
\hline S1 & 1 & Sample from Bad portion of the Road near AP Filling Station & $\begin{array}{l}\text { Lat. } 7^{0} 33^{\prime} 21^{\prime \prime} \mathrm{N} \\
\text { Long. } 5^{0} 12^{\prime} 50^{\prime \prime} \mathrm{E}\end{array}$ \\
\hline S2 & 2 & $\begin{array}{l}\text { Sample from Bad portion of the Road inside bush along the } \\
\text { Road }\end{array}$ & $\begin{array}{l}\text { Lat. } 7^{0} 32^{\prime} 36^{\prime \prime} \mathrm{N} \\
\text { Long. } 5^{0} 13^{\prime} 07^{\prime \prime} \mathrm{E}\end{array}$ \\
\hline S3 & 3 & $\begin{array}{l}\text { Sample from Bad portion of the Road inside bush along the } \\
\text { Road }\end{array}$ & $\begin{array}{l}\text { Lat. } 7^{0} 32^{\prime} 07^{\prime \prime} \mathrm{N} \\
\text { Long. } 5^{0} 13^{\prime} 13^{\prime \prime} \mathrm{E}\end{array}$ \\
\hline S4 & 4 & $\begin{array}{l}\text { Sample from Bad portion of the Road inside bush along the } \\
\text { Road }\end{array}$ & $\begin{array}{l}\text { Lat. } 7^{0} 31^{\prime} 35^{\prime \prime} \mathrm{N} \\
\text { Long. } 5^{0} 13^{\prime} 19^{\prime \prime} \mathrm{E} \\
\end{array}$ \\
\hline S5 & 5 & $\begin{array}{l}\text { Sample from Bad portion of the Road inside bush along the } \\
\text { Road }\end{array}$ & $\begin{array}{l}\text { Lat. } 7^{0} 31^{\prime} 09^{\prime \prime} \mathrm{N} \\
\text { Long. } 5^{0} 13^{\prime} 24^{\prime \prime} \mathrm{E}\end{array}$ \\
\hline S6 & 6 & $\begin{array}{l}\text { Sample from Good portion of the Road near APS Petrol } \\
\text { Filling Station }\end{array}$ & $\begin{array}{l}\text { Lat. } 7^{0} 33^{\prime} 39^{\prime \prime} \mathrm{N} \\
\text { Long. } 5^{0} 12^{\prime} 45^{\prime \prime} \mathrm{E}\end{array}$ \\
\hline S7 & 7 & Sample from Good portion of the Road after Ado Road exit & $\begin{array}{l}\text { Lat. } 7^{0} 32^{\prime} 47^{\prime \prime} \mathrm{N} \\
\text { Long. } 5^{0} 13^{\prime} 03^{\prime \prime} \mathrm{E}\end{array}$ \\
\hline S8 & 8 & Sample from Good portion of the Road near OJS Oil & $\begin{array}{l}\text { Lat. } 7^{0} 31^{\prime} 54^{\prime \prime} \mathrm{N} \\
\text { Long. } 5^{0} 13^{\prime} 15^{\prime \prime} \mathrm{E}\end{array}$ \\
\hline S9 & 9 & Sample from Good portion of the Road near Midec Oil & $\begin{array}{l}\text { Lat. } 7^{0} 31^{\prime} 33^{\prime \prime} \mathrm{N} \\
\text { Long. } 5^{0} 13^{\prime} 12^{\prime \prime} \mathrm{E}\end{array}$ \\
\hline S10 & 10 & $\begin{array}{l}\text { Sample from Good portion of the Road near Redeemed } \\
\text { Church of God }\end{array}$ & $\begin{array}{l}\text { Lat. } 7^{0} 31^{\prime} 10^{\prime \prime} \mathrm{N} \\
\text { Long. } 5^{0} 13^{\prime} 26^{\prime \prime} \mathrm{E}\end{array}$ \\
\hline
\end{tabular}
$=10^{-1} \mathrm{~cm} / \mathrm{sec}$., it is medium and $\mathrm{K}<10^{-1} \mathrm{~cm} / \mathrm{sec}$., it is

Table 1: The details of the soil samples

\section{III.RESULTS AND DISCUSSION}

Table 2 shows the results of permeability and coefficient of uniformity using grain sizes for all the samples. The permeability values obtained ranges from $1.73 \times 10^{-6} \mathrm{~mm} / \mathrm{s}$ to $2.15 \times 10^{-3} \mathrm{~mm} / \mathrm{s}$. These indicated that their permeability is very low (i.e. $\mathrm{K}<10^{-1} \mathrm{~cm} / \mathrm{sec}$.), though well graded soil (i.e. $\mathrm{C}_{\mathrm{u}}>5$ ). Low permeability shows that the soil in the study area retains water, which suggests that there is presence of large contents of clay / silt in the soil [9]. Thus, the soil becomes plastic under pressure from road surface, which might have resulted in pavement failure in some parts of the road. The permeability of the soil samples is in descending order of S1 $>$ $\mathrm{S} 9>\mathrm{S} 4>\mathrm{S} 5>\mathrm{S} 7>\mathrm{S} 8>\mathrm{S} 10>\mathrm{S} 3>\mathrm{S} 6>\mathrm{S} 2$. 
International Journal of Trend in Scientific Research and Development (IJTSRD) ISSN: 2456-6470

Table 2: Results of Coefficient of Uniformity (Cu) and Permeability (K) using Grain Size Distribution

\begin{tabular}{|l|l|l|l|l|l|l|l|}
\hline Sample & $\begin{array}{c}\mathbf{D}_{60} \\
(\mathbf{m m})\end{array}$ & $\begin{array}{c}\mathbf{D}_{10} \\
(\mathbf{m m})\end{array}$ & $\mathbf{C u}$ & $\begin{array}{c}\mathbf{D}_{50} \\
(\mathbf{m m})\end{array}$ & $\begin{array}{c}\mathbf{D}_{50}^{2} \\
(\mathbf{m m})\end{array}$ & $\begin{array}{c}\mathbf{K} \\
(\mathbf{m m} / \mathbf{s e c})\end{array}$ & $\begin{array}{c}\text { Grading } \\
\text { Type }\end{array}$ \\
\hline S1 & 0.50 & 0.004 & 128 & 0.250 & 0.60250 & $2.15 \mathrm{E}-03$ & Well graded \\
\hline S2 & 0.57 & 0.066 & 9 & 0.022 & 0.00048 & $1.73 \mathrm{E}-06$ & Well graded \\
\hline S3 & 0.25 & 0.006 & 45 & 0.100 & 0.01000 & $3.57 \mathrm{E}-05$ & Well graded \\
\hline S4 & 0.29 & 0.040 & 7 & 0.250 & 0.06250 & $2.23 \mathrm{E}-04$ & Well graded \\
\hline S5 & 0.28 & 0.040 & 7 & 0.200 & 0.04000 & $1.43 \mathrm{E}-04$ & Well graded \\
\hline S6 & 0.06 & 0.001 & 45 & 0.062 & 0.00384 & $1.37 \mathrm{E}-05$ & Well graded \\
\hline S7 & 0.23 & 0.008 & 31 & 0.190 & 0.03610 & $1.29 \mathrm{E}-04$ & Well graded \\
\hline S8 & 0.28 & 0.003 & 82 & 0.120 & 0.01440 & $5.14 \mathrm{E}-05$ & Well graded \\
\hline S9 & 0.74 & 0.002 & 493 & 0.310 & 0.09610 & $3.43 \mathrm{E}-04$ & Well graded \\
\hline S10 & 0.70 & 0.002 & 389 & 0.110 & 0.01210 & $4.32 \mathrm{E}-05$ & Well graded \\
\hline
\end{tabular}

Table 3 shows the results of permeability using Falling Head method for all the samples. The permeability values obtained ranges from $8.46 \times 10^{-2} \mathrm{~cm} / \mathrm{s}$ to $1.23 \times 10^{-1} \mathrm{~cm} / \mathrm{s}$. These portrayed that their permeability ranges from low to high (i.e. $\mathrm{K}<10^{-1} ; \mathrm{K}>10^{-1} \mathrm{~cm} / \mathrm{sec}$.). S2, S3, S4 and S5 soils have high permeability, which shows that they allow free flow of water through them. This suggested that there is presence of large contents of granular materials in the soils e.g. sand [9]. Part of road on these soils is liable to failure due to other Engineering factors. Additionally, their permeability is in descending order of S3 $>$ S5 $>$ S4 $>$ S2. On the other hand, S1, S6, S10, S7, S9 and S8 have low permeability, which shows that they retain water and have presence of large contents of clay/ silt materials. Road failure on these soils are likely to be as a result of high soil plasticity, though other Engineering factors are not ruled out. Their permeability is in descending order of S1 > $\mathrm{S} 6>\mathrm{S} 10>\mathrm{S} 7>\mathrm{S} 9>\mathrm{S} 8$.

Table 3: Results of Permeability Test using Falling Head method

\begin{tabular}{|c|c|c|c|c|c|c|c|}
\hline Sample & $\begin{array}{c}\text { Head } \\
\left(h_{1}\right) \\
\end{array}$ & $\begin{array}{l}\text { Head } \\
\left(h_{2}\right)\end{array}$ & $\mathrm{t}_{1}$ (Sec.) & $\begin{array}{c}t_{2} \\
(\text { Sec. }) \\
\end{array}$ & $\mathrm{T}\left(\mathrm{t}_{2}-\mathrm{t}_{1}\right)($ Sec. $)$ & $\begin{array}{l}\log 10 \\
\left(h_{1} / h_{2}\right) \\
\end{array}$ & $\begin{array}{c}\mathrm{K} \\
(\mathrm{cm} / \mathrm{sec} .)\end{array}$ \\
\hline S1 & 110 & 50 & $2.63 D e$ & 7.510 & 4.88 & 0.34 & $9.89 \mathrm{E}-02$ \\
\hline S2 & 110 & 50 & 2.25 & 6.84 & 4.59 & 0.34 & $1.05 \mathrm{E}-01$ \\
\hline S3 & 110 & 50 & 2.54 & 6.48 & 3.94 & 0.34 & $1.23 \mathrm{E}-01$ \\
\hline S4 & 110 & 50 & 2.92 & 7.32 & 4.40 & 0.34 & $1.10 \mathrm{E}-01$ \\
\hline S5 & 110 & 50 & 2.77 & 6.92 & 4.15 & 0.34 & $1.16 \mathrm{E}-01$ \\
\hline S6 & 110 & 50 & 3.71 & 8.65 & 4.94 & 0.34 & $9.78 \mathrm{E}-02$ \\
\hline S7 & 110 & 50 & 3.54 & 8.92 & 5.38 & 0.34 & 8.98E-02 \\
\hline S8 & 110 & 50 & 3.1 & 8.81 & 5.71 & 0.34 & $8.46 \mathrm{E}-02$ \\
\hline S9 & 110 & 50 & 3.55 & 9.22 & 5.67 & 0.34 & $8.52 \mathrm{E}-02$ \\
\hline $\mathrm{S} 10$ & 110 & 50 & 3.33 & 8.68 & 5.35 & 0.34 & $9.03 \mathrm{E}-02$ \\
\hline
\end{tabular}

Generally, the results of the two methods of permeability used were at variance with each other. Grain size permeability method showed that all the soil samples have low permeability while Falling head permeability showed that the soil permeability ranges from low to high. Nevertheless, both methods agreed that S1, S6, S10, S7, S9 and S8 have low permeability.

\section{Conclusion}

From the above study, some soil samples (i.e. S2, S3, S4 and S5) have high permeability, while others have low permeability. All the soil samples were wellgraded i.e. good representative of soil types. The Falling head permeability method showed that the soil permeability ranges from low to high, which correlates with present condition of the road observed during field assessment. Permeability from Grain size method showed that all the soil samples have low permeability, which portrayed high contents of clay and its mineral in the soil of the study area. Thus, the soil retains water. The soil samples with high permeability portrayed high contents of granular materials (sand), which means allowance of free flow 
of water in the soil. There is need for further study in order to ascertain the actual causes of road failure along the road.

\section{References}

1. Adams, J.O. and Adetoro, A. E., "Quality Assessments of Water in Selected Waste Dumping Site Areas," International Journal of Scientific Research and Education, vol. 2(11), pp. 2399 - 2404, 2014b.

2. Adetoro, A. E. and Adams, J.O., "Analysis of Influences of Waste - Dumping Sites on the Quality of Water," IOSR Journal of Mechanical and Civil Engineering (IOSR-JMCE), vol. 11(6 ver. IV), pp. $27-30,2014$.

3. Bayewu O. O., Olufemi S. T. and Adewoye, A. O., "Permeability Characteristics of some Subgrade Soil along Highway," International Journal of Novel Research in Engineering and Applied Sciences (IJNREAS), vol. 2(1), pp. 1 - 7, 2013.

4. Ifada, P. T., Kasali, I. A., Makanjuola, P. I. and Monye, O. A. "Assessment of Permeability Characteristics of Sub-Grade Soil along Failed Sections of Ado-Ikere Road, South-Western
Nigeria," Nigeria, Ado-ekiti, The Federal Polytechnic, Dept. of Civil Engineering: HND Dissertation (Unpublished), 2015.

5. American Association of State Highway and Transportation Officials - AASHTO, "Classification of Soil and Soil Aggregate Mixture for Highway Construction Purposes," USA, Washington DC: AASHTO, Vol. 1, 2001.

6. British Standard 1377 - BS 1377, "British Standard Methods of Test for Soils for Civil Engineering Purposes," UK, London: British Standards Institution, 1990.

7. Ekiti State Directorate of ICT, "The Official Website of the Government of Ekiti State, Nigeria,"

https://ekitistate.gov.ng/administration/local-govt/, 30 May,, 2018.

8. Elhakim, A. F. "Estimation of Soil Permeability," Alexandria Engineering Journal, vol. 55, pp. 2631 -2638, 2016.

9. Ola, S.A, "Essentials of Geotechnical Engineering," Nigeria, Ibadan, Jericho: University Press Plc, 2013. 